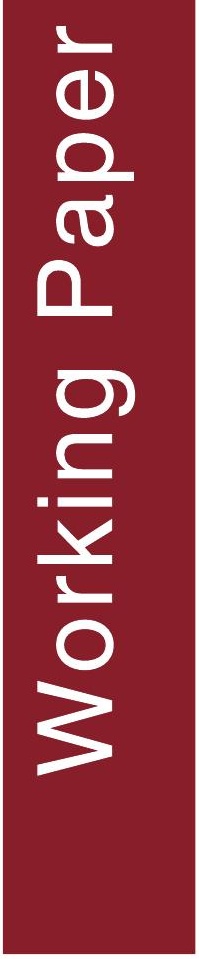

Desi Ariyadhi Suyamto, Meine van Noordwijk, Betha Lusiana, Andree Ekadinata and Ni'matul Khasanah 


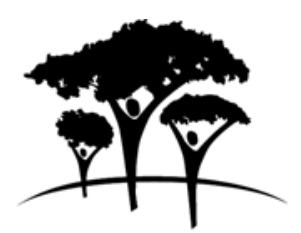

\section{World Agroforestry Centre}

Correct citation: Suyamto DA, van Noordwijk M, Lusiana B, Ekadinata A and Khasanah N. 2006.

Prospects of adoption of tree-based systems in a rural landscape and its likely impacts on carbon stocks and farmers' welfare: the FALLOW Model Application in Muara Sungkai, Lampung, Sumatra, in a 'Clean Development Mechanism' context. ICRAF Working Paper no 14. Bogor: World Agroforestry Centre (ICRAF), Southeast Asia Regional Programme.

Titles in the Working Paper Series aim to disseminate interim results on agroforestry research and practices and stimulate feedback from the scientific community. Other publication series from the World Agroforestry Centre include: Agroforestry Perspectives, Technical Manuals and Occasional Papers.

Published by the World Agroforestry Centre (ICRAF)

Southeast Asia Regional Programme.

ICRAF Southeast Asia Regional Office

Jl. CIFOR, Situ Gede, Sindang Barang, Bogor

16680 PO Box 161, Bogor 16001, Indonesia

Tel: 62251 625415, fax: 62251625416

Email: icraf-indonesia@cgiar.org

ICRAF Southeast Asia website: http://www.icraf.cgiar.org/sea or

http://www.worldagroforestrycentre.org/sea

(C) Copyright ICRAF Southeast Asia 2006

ICRAF Working Paper nr 14

The views expressed in this publication are those of the author(s) and not necessarily those of the World Agroforestry Centre.

Articles appearing in this publication may be quoted or reproduced without charge, provided the source is acknowledged. No use of this publication may be made for resale or other commercial purposes.

All images remain the sole property of their source and may not be used for any purpose without written permission of the source.

The geographic designation employed and the presentation of material in this publication do not imply the expression of any opinion whatsoever on the part of the World Agroforestry Centre concerning the legal status of any country, territory, city or area or its authorities, or concerning the delimitation of its frontiers or boundaries. 


\title{
Prospects of adoption of tree-based systems in a rural landscape and its likely impacts on carbon stocks and farmers' welfare: the FALLOW Model Application in Muara Sungkai, Lampung, Sumatra, in a "Clean Development Mechanism" context ${ }^{1}$
}

\author{
Desi Ariyadhi Suyamto, Meine van Noordwijk, Betha Lusiana, Andree Ekadinata and Ni'matul Khasanah ${ }^{2}$
}

\begin{abstract}
Environmental services provided by a landscape, including carbon stocks stored, depend on land use patterns. Adoption of land use practices among choices of land use systems in a rural landscape depends on farmers' strategic decisions in allocating land and tactical decisions in allocating labour, both likely to be based on the results farmers expect to obtain, and strongly conditioned by capital availability. Their expectations gradually change on the basis of local experience, and are influenced by external information sources (knowledge diffusion from elsewhere and 'extension' or the priming of expectations for land use practices that are not yet widespread). At the local community scale, specific restrictions on land use options are set, and issues such as fire control are determined by the cohesiveness of the local community. Prices of the various commodities and their volatility are determined by the surrounding economy, as does the wage rate for off-farm and out-of-thelandscape labour opportunities. The overall outcome of the dynamic land use mosaic determines the amount of biomass and carbon stocks of the landscape. The FALLOW model was designed to provide a comprehensive description of the factors and interactions described above, to allow the testing of hypotheses about 'causal' explanations (including the various direct and indirect feedbacks) and to evaluate 'scenarios' of 'baseline' and policy-change land use evolution. Baselines are important in the discussion of 'environmental service rewards', while the likely response to 'rewards' can include 'perverse incentives' and 'leakage', if additional capital relieves constraints to the development of less-environmental friendly land use options. This paper reports results on prospective analyses using the FALLOW model on adoption of land use systems by transmigrant and local farmers in lowland peneplain of Muara Sungkai, Lampung, Sumatra. Specific focus was to compare a 'project' (rapid tree planting in a limited area) approach to a programmatic one (facilitating spontaneous tree adoption in a larger area) in terms of carbon-stocks gains and projected effects on farmers' welfare, in a 'clean development mechanism' context. The results suggested that a 'project' approach was likely able to increase carbon stocks without leakage in a short-term monitoring period. However a reduction of carbon stocks below baseline ('leakage') can be expected in the longer term if the tree planting approach did not provide off-farm employment opportunities to surrounding farmers. If costs of 'extension' and 'social control on fire' are assumed to be zero, the 'programmatic' approach to removing constraints to spontaneous smallholder adoption was likely able to increase both carbon stocks and farmers' welfare better than the simulated 'project' approach.
\end{abstract}

Keywords: carbon, 'clean development mechanism', farmers' decision, farmers' welfare, landscape, model, 'project' approach, 'programmatic' approach.

\footnotetext{
${ }^{1}$ Paper presented at International Consultation Workshop on Smallholder Agroforestry Options for Degraded Soils, Batu, East Java, Indonesia, 18-21 August 2005

${ }^{2}$ All authors are with the World Agroforestry Centre (ICRAF) Southeast Asia Programme, Bogor, Indonesia. Correspondence: Desi A. Suyamto (d.suyamto@cgiar.org)
} 


\section{INTRODUCTION}

Much of the rural landscape of Southeast Asia has been developed from a basis of 'shifting cultivation' and fallow-crop rotations into a diverse mosaic of permanent cropping, agroforestry systems, forest patches (used for non-timber products as well as timber harvesting) and fire-climax Imperata grasslands. The primary agents of change are the farmers who make their strategic decisions on land use patterns and tactical decisions on labour allocations, both likely to be based on the results they expect to obtain, and strongly conditioned by capital availability. Their expectations gradually change on the basis of local experience, and are influenced by external information sources (knowledge diffusion from elsewhere and 'extension' or the priming of expectations for land use practices that are not yet widespread). At the local community scale, specific restrictions on land use options are set, and issues such as fire control are determined by the cohesiveness of the local community. Prices of the various commodities and their volatility are determined by the surrounding economy and its infrastructure, as does the wage rate for off-farm and out-of-the-landscape labour opportunities. The overall outcome of the dynamic land use mosaic determines the amount of biomass and carbon stocks of the landscape, the way incoming rainfall is processed into river flow (peak flow and base flow) and the opportunities for flora and fauna of pioneer-to-late successional species groups to make a living along with the people in the landscape.
The FALLOW model (Van Noordwijk, 2002; Suyamto and Van Noordwijk, 2005) was designed to provide a comprehensive description of the factors and interactions described above. The main purpose of designing the model was to allow the testing of hypotheses about 'causal' explanations of response to specific interventions (including the various direct and indirect feedbacks) and to evaluate 'scenarios' of 'baseline' and 'policy-change' conditions for their effect on land use evolution (Figure 1). Gladwell (2005) described the process of reducing complex information supply into a core set of essentials as 'thin slicing' and this is what modeling in essence is about: leaving out as much of the complexity of reality as we dare to do (through formal assumptions) to still maintain the essential features of our system of study. As precaution, evaluation of scenarios in this context is not intended as 'prediction', because prediction means: "speaking about the future before it happens" that in the end will degenerate into speculation when it deals with complexity and uncertainty (Peterson et al., 2003; Voros, 2005). Instead, such evaluation is similar to what was termed by Voros (2005) as prospection or forward viewing, based on a specific constellation of driver variables or scenarios to provide foresight of drivers' changes, reveal the implications of baseline trajectories, and illuminate options for 'future' action (Peterson et al., 2003). Baselines are important in the discussion of 'environmental service rewards', while the likely response to 'rewards' can include 'perverse incentives' and 'leakage', if additional capital relieves constraints to the development of less-environmental friendly land use options.

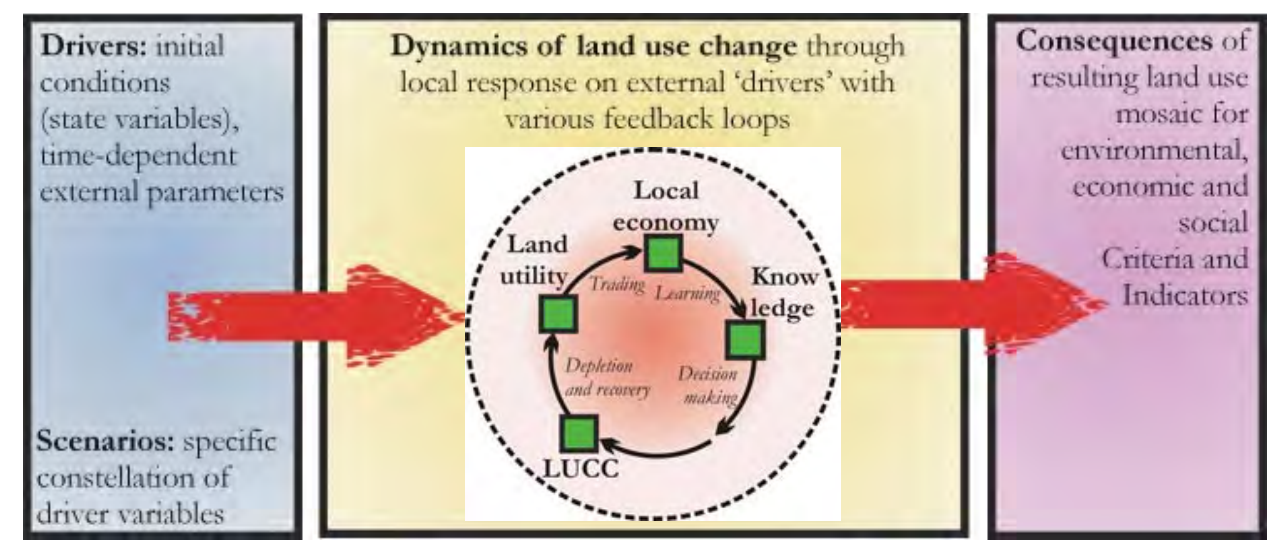

Figure 1. Generic structure of a model that translates 'driver' or exogenous variables to the time bound responses in a landscape, which has consequences ('externalities' in as far as they are not part of the feedback loops in the dynamic section) for criteria and indicators of system performance; scenarios refer to specific combinations of driver variables that represent changes in higher level systems. Source: Suyamto and Van Noordwijk (2005). 


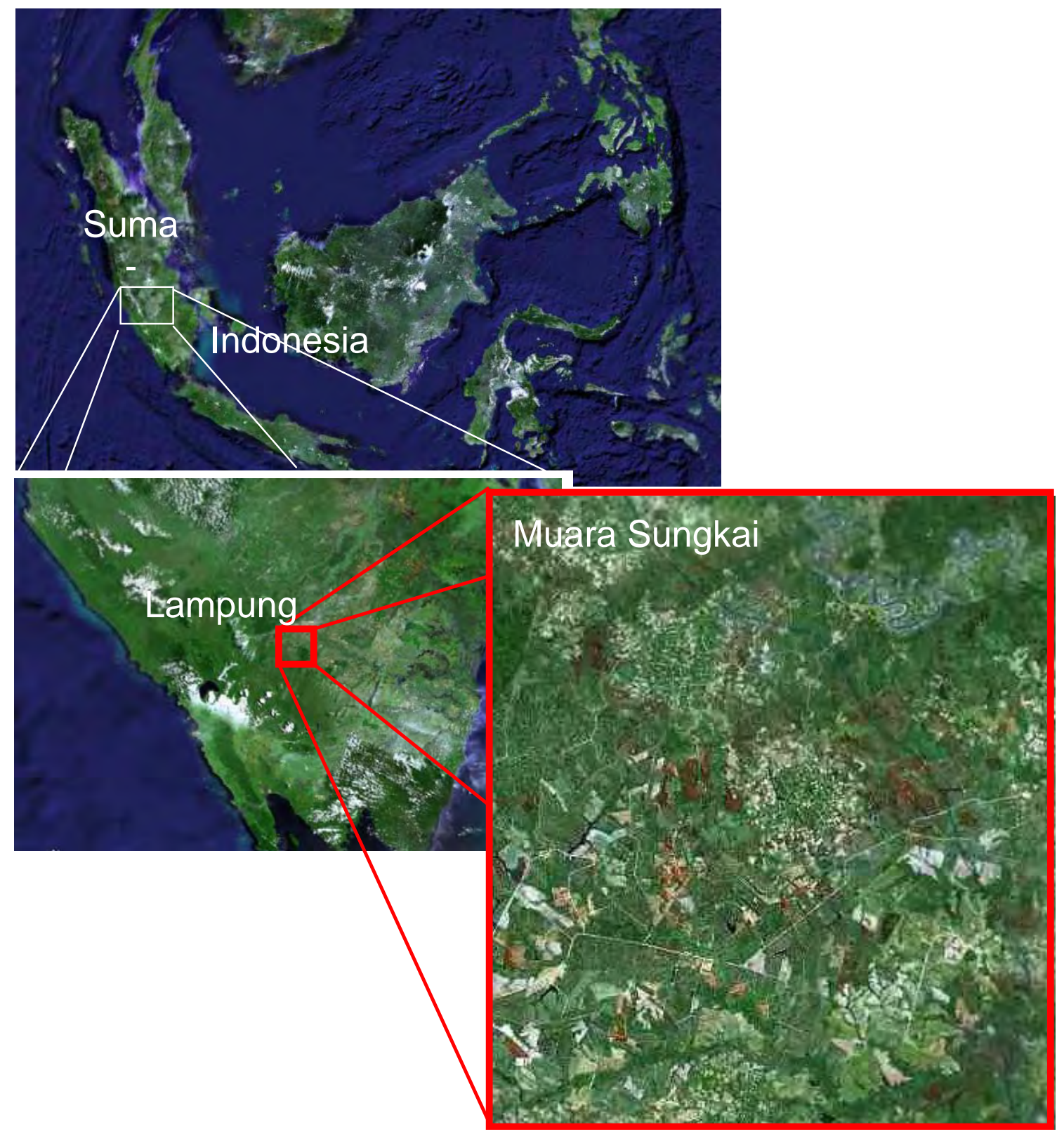

Figure 2. Location of Muara Sungkai study area as part of Lampung province in Sumatra, Indonesia

This paper reports results on prospective analyses using the FALLOW model on likely adoption of land use systems by transmigrant and local farmers in the lowland peneplain of Muara Sungkai, Lampung, Sumatra. (Fig. 2). This area was selected as the 'degraded lands' benchmark for the Alternatives to Slash and Burn program in 1993 (Van Noordwijk et al., 1995) and has subsequently become the focus of the 'Smallholder Agroforestry on Degraded Soils' (SAFODS) research project that compares smallholder timber production with those aimed at transitions to rubber or oil palm production. The treebased systems are expected to become a more profitable and sustainable land use compared to the cassava and sugarcane production that were the main stay of the local economy in the 1990's. In fact these tree crops are already gaining in importance, but there are set backs through uncontrolled fire, conflicts over land (Budidarsono et al., 2005) and uncertainty by farmers on the choice of new technologies in the absence of effective extension services

Specific focus of our modeling effort was to compare a 'project' (rapid tree planting in a limited area) approach to a 'programmatic' one (facilitating spontaneous tree adoption in a larger area) in terms of carbon-stock gains and projected effects on farmers' welfare, in a 'clean development mechanism' context. 


\section{OBJ ECTIVES}

Five steps in the prospective analyses were done to answer the following questions:

Do we understand the actual changes on the basis of the 'drivers' in the model for 1990-2002 period?

What is the likely 'baseline' for land use change, cstocks and income for 2002-2031 period?

What can we expect from better fire control for 2002-2031 period?

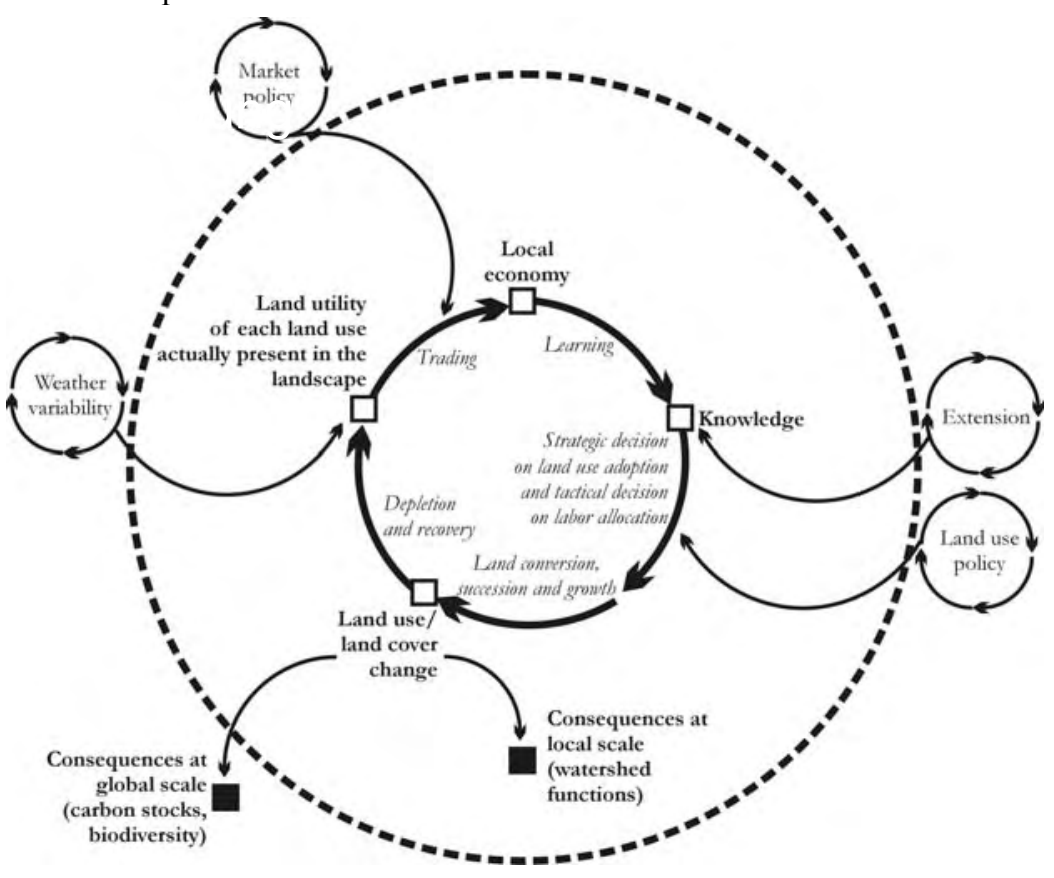

Which changes in drivers are required for rapid adoption of smallholder timber systems, as form of 'clean development mechanism' for 2002-2031 period?

What 'additionality' and 'leakage' can we expect for a 'timber plantation' project approach, potentially replacing the existing sugarcane plantation, for 20082012 (commitment) period and for longer period (2002-2031)?

Figure 3. Key relationships considered in the main dynamic loop of the FALLOW model (land utility, local economy and land use decision) that determine the spatial pattern of land cover, and the modules that translate this pattern into consequences for environmental service functions such as C storage. External 'drivers' (small loops) may take a role in the dynamics by affecting local response through trading (e.g. market policy made by distant agents), knowledge (e.g. extension conducted by distant agents), decision-making process (e.g. land use policy made by distant agents) or land utility (e.g. weather variability as results of global climatic processes). Source: Suyamto and Van Noordwijk (2005)

\section{CONCEPTUAL FRAMEWORK OF THE FALLOW MODEL}

FALLOW Model is a spatially explicit model of landscape dynamics. It is a 'thin-slice' understanding on farmers' decision making with regards to choices of land use systems on a landscape by simulating: (i) how those land use systems extract natural stocks, (ii) how the natural stocks replenish, (iii) how farmers learn about the benefits of existing options of land use systems, (iv) how they make deliberate decisions regarding capital allocation on each land use system, and (v) what are the consequences on such landscape dynamics processes (Figure 3).

\section{RESULTS}

1. Model validity test: can we trace the limiting capitals steps for the early

\section{adoption of rubber-based systems that start to transform landscape dynamics in Muara Sungkai?}

When the landscape of Muara Sungkai was still dominated by Imperata grasslands, as the likely patterns found in 1990, the adoption of smallholder rubber plantations was strongly conditioned by lack of financial capital for establishment of (Figure 4). Thus, without financial aid from others, it was impossible to have the landscape patterns that have been achieved in the most recent state, where rubber plantation systems have been largely adopted by farmers. Figure 4 shows the likely landscape dynamics if farmers did not get financial aid for rubber plantation establishment at the early stage of adoption when the system was not yet widespread. 

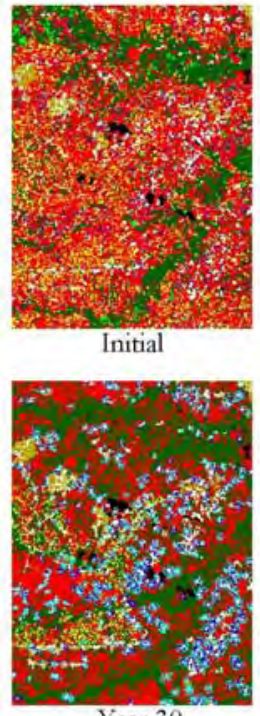

Year 30

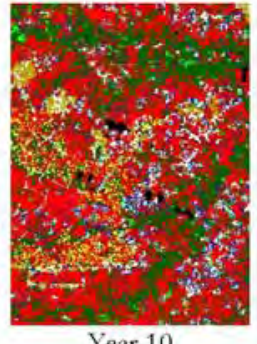

Year 10

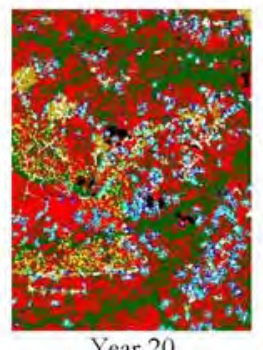

Year 20

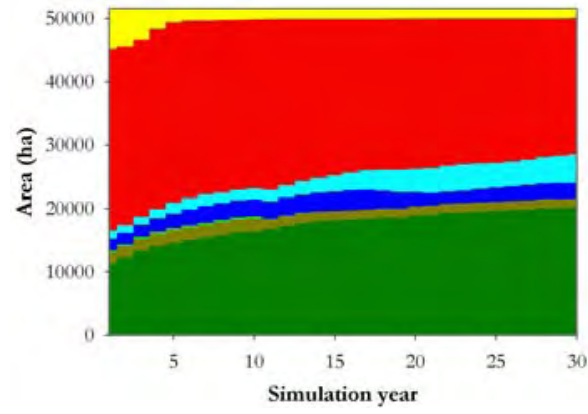

Land use type

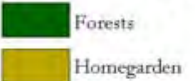

Timber plantation

Imperata/fallow

Cassava

प Sugarcane

Rubber plantation

Oil palm plantation

Settlements

Figure 4. Prospects of landscape dynamics from rubber-based systems adoption scenario at early stage over 3 decades without financial aid.

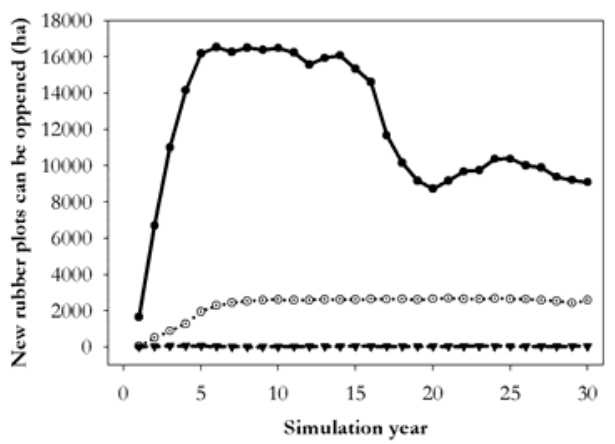

$\rightarrow$ Based on land capital

$-\rightarrow-$ Based on financial capital

Figure 5. Limiting capitals in rubber-based systems adoption at early adoption stage over 3 decades without financial aid.

Once financial aid in form of grant $(\mathrm{Rp} 5,000,000$ per year) was given to farmers for rubber plantation establishment, the rubber adoption was revolutionarily boosted until more than half of the landscape was dominated by rubber (Figure 6). The limiting capitals of rubber plantation systems adoption shifted from financial capital to land and labour capitals starting from the year 13, which indicated the effective period of financial grant disbursement (Figure 7). 


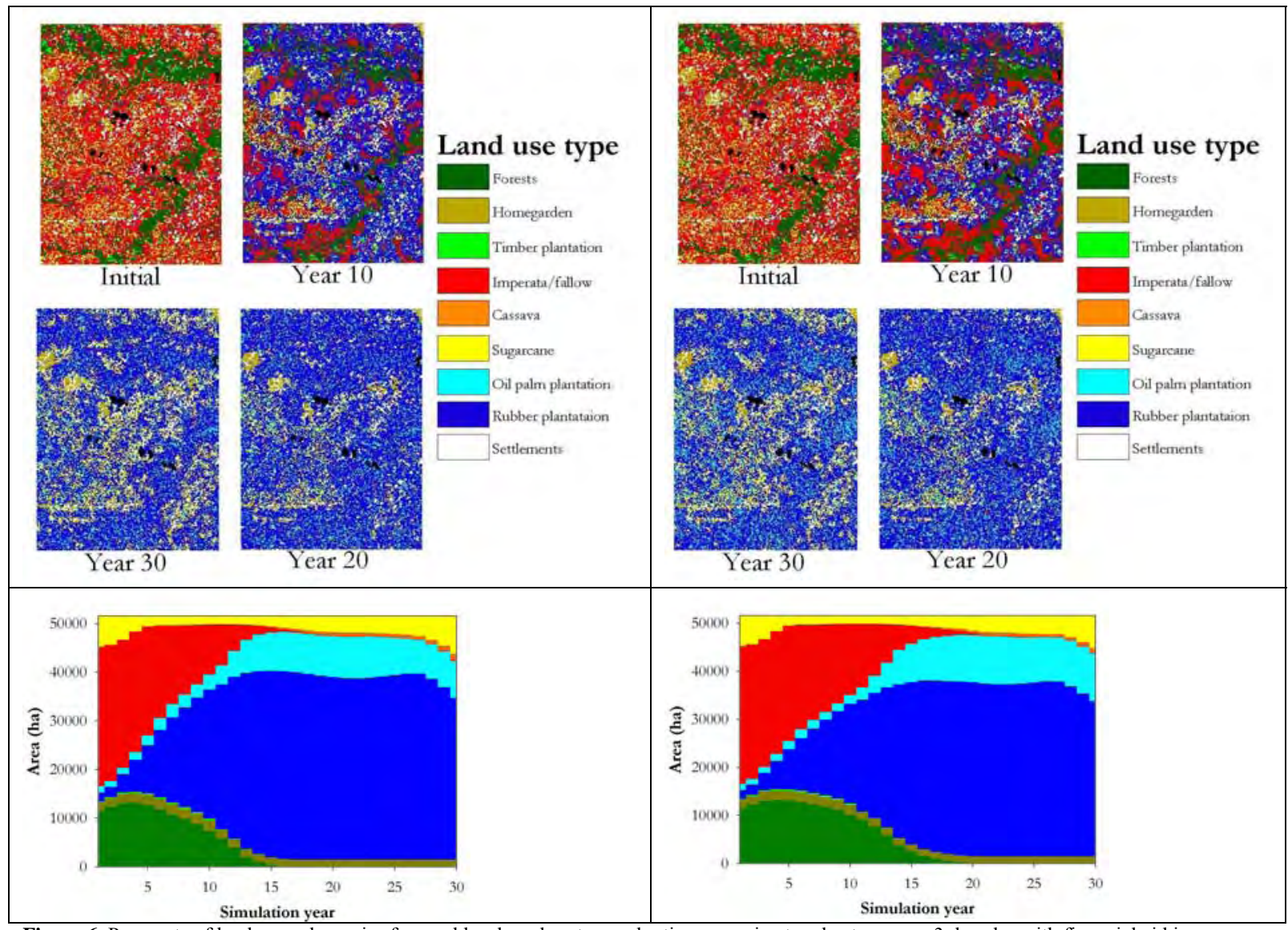

Figure 6. Prospects of landscape dynamics from rubber-based systems adoption scenario at early stage over 3 decades with financial aid in form of grant (left) or loan (right).
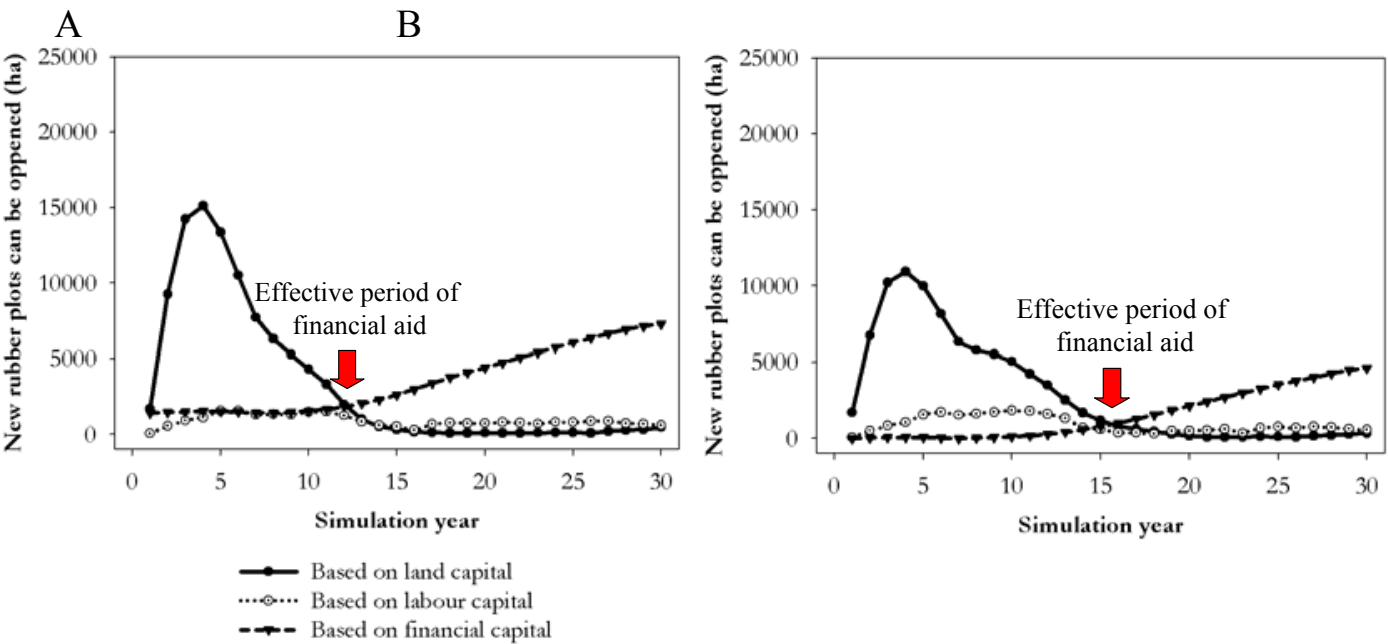

Figure 7. Limiting capitals in rubber-based systems adoption at early adoption stage over 3 decades with financial aid in form of grant (A) or loan (B)

Similar prospect on revolutionary rubber plantation adoption was found when financial aid was given in form of loan (Figure 6B). The limiting capitals of rubber plantation systems adoption shifted from financial capital to land and labour capitals starting from the year 16, which indicated the effective period of financial loan disbursement (Figure 7B).
Farmers likely stopped taking the loan for rubber plantation establishment starting from the year 14 (Figure 8). 


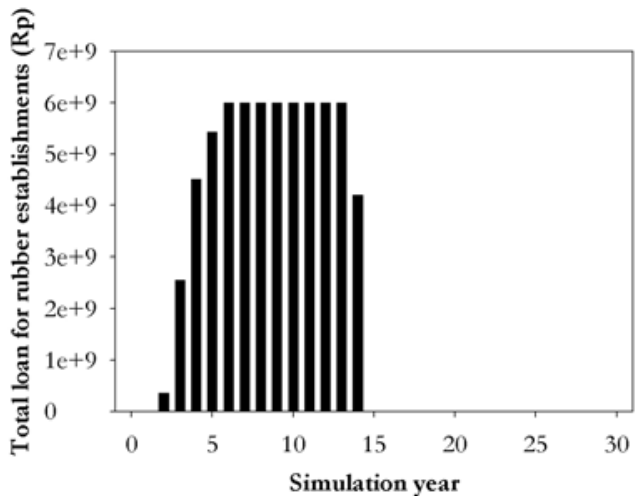

Figure 8 . Total loan taken by farmers for new rubber plantation establishments

Compared to condition when farmers did selffinancing in rubber plantation establishment at the early stage of adoption, financial aid in form of grant or loan likely depleted landscape c-stocks within the first 2 decades due to large-scale rubber plantation establishments, but would replenish landscape cstocks in the last decade when most of rubber plantations have reached the 'mature' state (Figure 9).

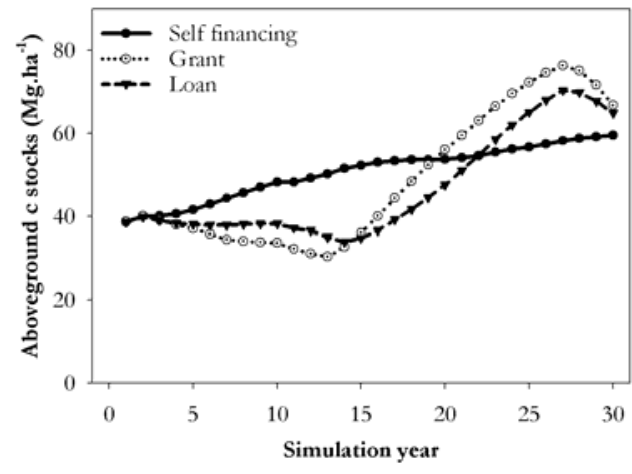

Figure 9. Prospects of c-stocks dynamics at various financial generating scenarios for rubber-based systems establishment at early adoption stage over 3 decades. term of improving farmers' welfare, financial aid in form of grant or loan for rubber plantation establishment likely increased non-food expense of farmers
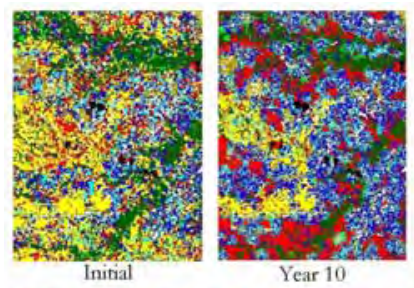

Land use type
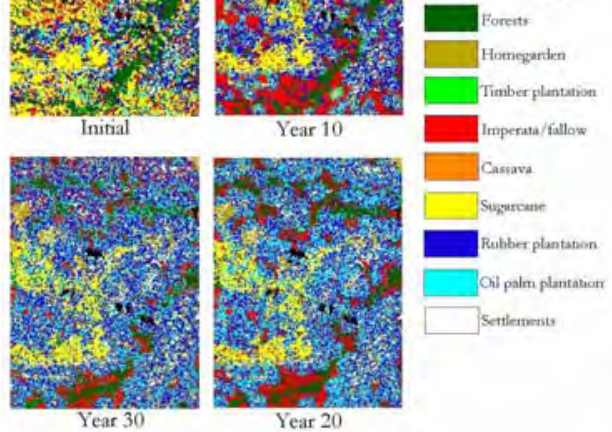

starting from the first decade, compared to condition without financial aid (Figure 10).

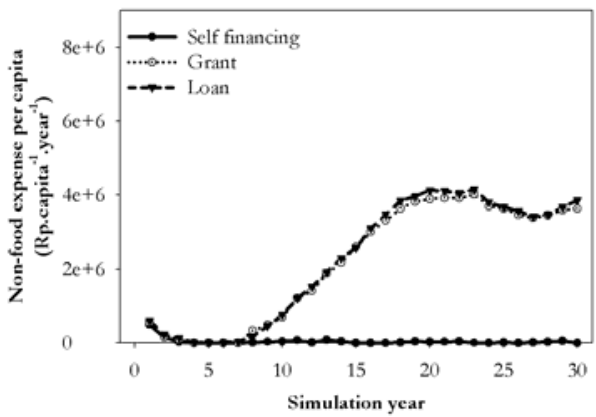

Figure 10. Prospects of farmers' welfare at various financial generating scenarios for rubber-based systems establishment at early adoption stage over 3 decades.

It can be concluded that current rubber plantation adoption by farmers in Muara Sungkai was due to financial aid (can possibly be in form of either grant or loan) for its establishment at the early stage of the adoption, although the simulation was not able to suggest the precise amount of such aid due to lack of historical data on it. For the 'baseline' projection presented in the next part, which was initialized using actual land cover map of the area in the year 2002 , it is assumed that farmers have generated financial capitals by themselves without financial aid at all for the new rubber plantation establishment.

\section{Prospecting the baseline}

Initialized using land cover map of the area in the year 2002, baseline projection was made over 3decade period, in order to prospect the likely 'baseline' landscape dynamics. If the 'drivers' do not change from the 'baseline' setting, the landscape patterns of Muara Sungkai will likely be dominated by rubber plantations, competing with oil palm plantations and sugarcane plantations (Figure 11).

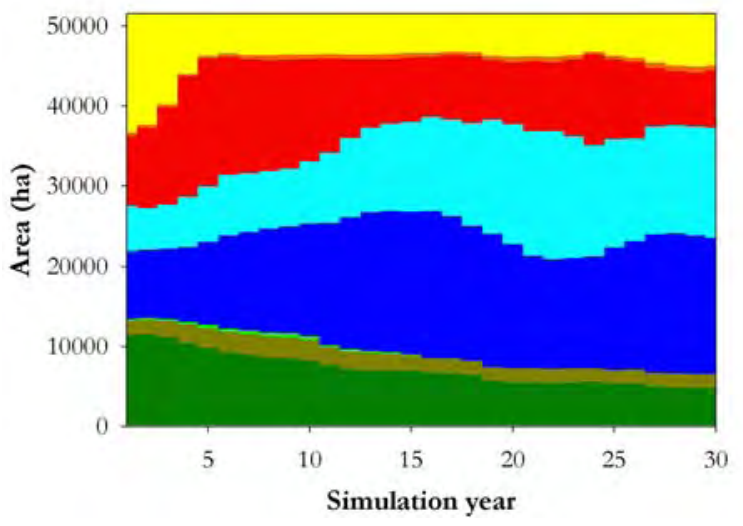

Figure 11 Prospects of landscape dynamics from the baseline simulation over 3 decades 
From visual comparison between simulated land cover map of the year 2005, which was colored in green palette, and the satellite imagery of the area taken from Google Earth in the same year, the general patterns of the 'baseline' projection seemed approaching the general patterns of the actual map, although not in a good precision (Figure 12).

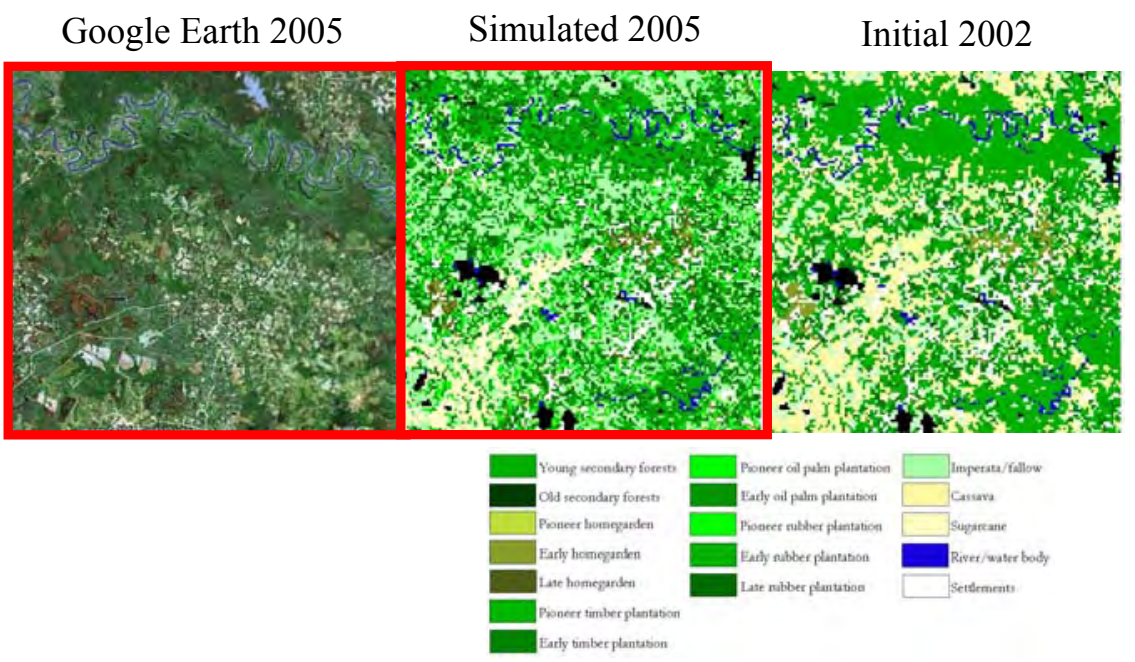

Figure 12. Visual comparison between simulated baseline and satellite imagery of the year 2005 .

Relatively slow increases in either c-stocks (Figure 13) or farmers' welfare (Figure 14) were resulted by 'baseline' projection. Therefore, 'scenario-based

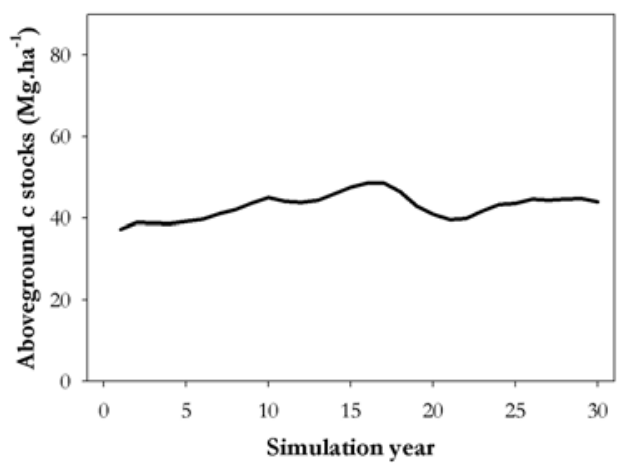

simulations' in the next parts were aimed to prospect possibility to increase both c-stocks and farmers' welfare in the area.

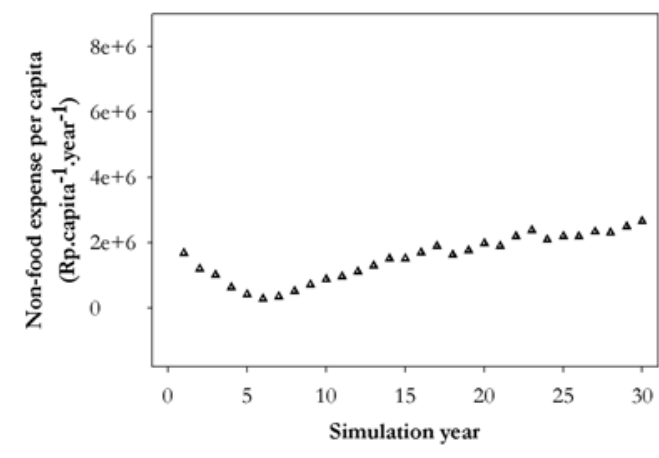

Figure 13. Prospects of c stocks dynamics and farmers' welfare from the baseline simulation over 3 decades.

\section{Prospecting the social control on fire}

Based on validation of simulated fire from the 'baseline' projection to the actual fire data obtained from NOAA, it was found that effective radius of social control on fire in the landscape of Muara Sungkai was around $2.5 \mathrm{~km}$ from the settlements (Figure 14). Thus, this part was aimed to prospect the gains in c-stocks and farmers' welfare if social quotient in controlling fire is getting worst or getting better from the 'baseline' setting.

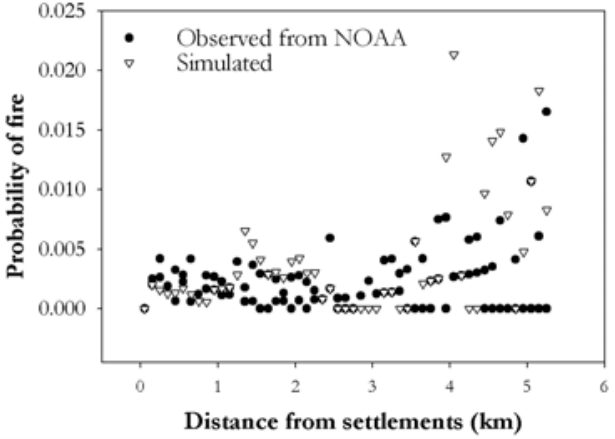

Figure 14. Fire validation from the baseline simulation. 
When the community can do better control on fire, fire-climax Imperata grasslands can significantly be reduced from the landscape (Figure 15). But, it does not imply that better social control on fire corresponds to more tree-based systems adoption (Figure 16), causing to relatively small increase on landscape c-stocks (Figure 17). Unchanged farmers' welfare when community took better control on fire (Figure 18) may explain on slow adoption on fire control managements (introduced by some related projects) by farmers.

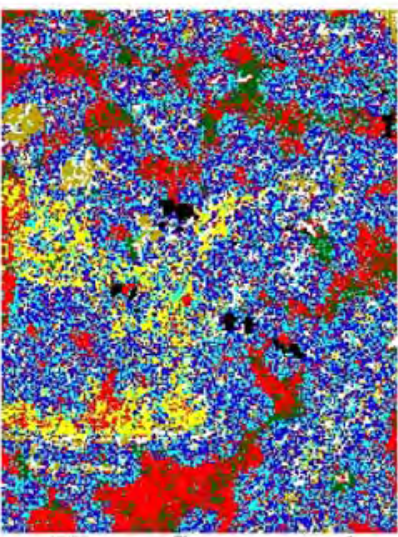

Worst fire control

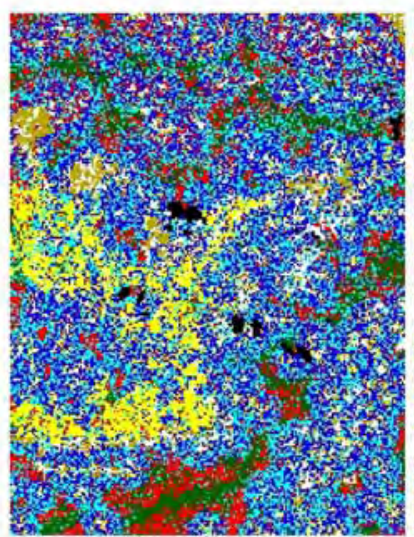

Baseline

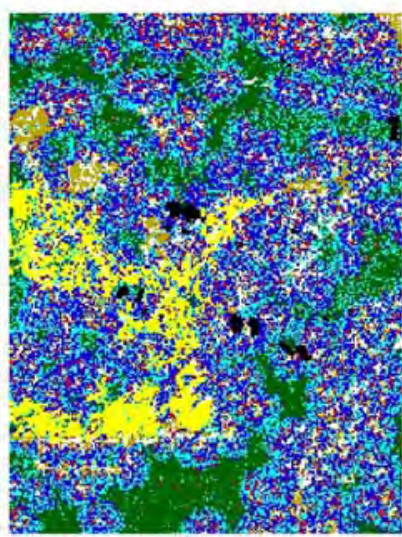

Better fire control

\section{Land use type}
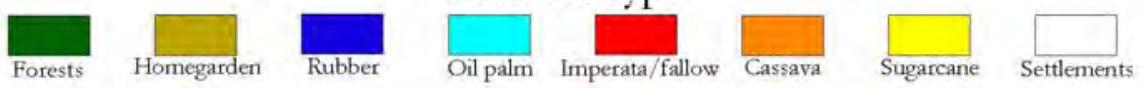

Figure 15. Prospects of final patterns of simulated landscape in the year-30 at various fire control scenarios.
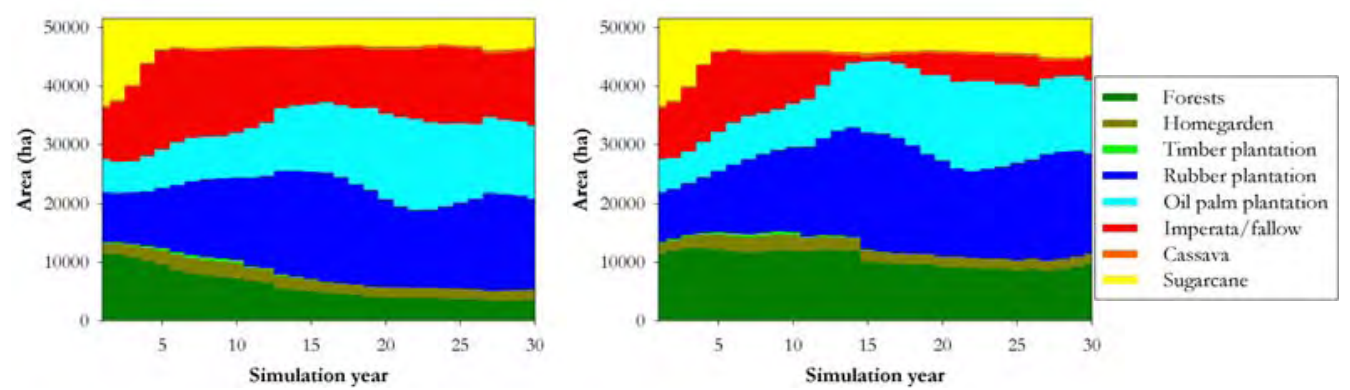

Figure 16. Prospects of landscape dynamics at various fire control scenarios over 3 decades.
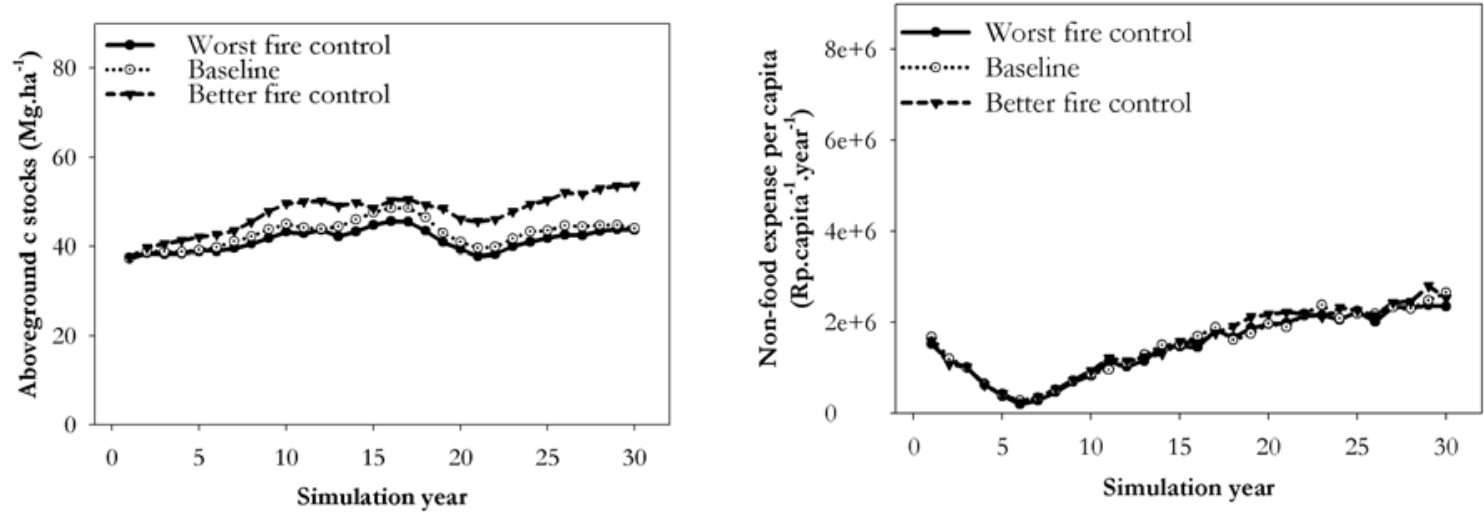

Figures $17 \& 18$. Prospects of c-stocks dynamics and farmers' welfare at various fire control scenarios over 3 decades. 


\section{Prospecting the adoption of smallholder timber-based systems}

In this part, adoption of smallholder timber-based systems was prospected, to explore the most significant driver to boost the adoption: whether it is related to market attraction of timber or to extension. Combined effect of market attraction, extension and better fire control was also prospected.

Improvement on timber market as such would likely not attract farmers to adopt timber-based systems (Figure 19 A and Figure $20 \mathrm{~A}$ ), since the risk due to relatively long time lag of timber-based systems would affect farmers' priming on expectation. When extension on smallholder timber-based systems was able to convince farmers by reducing their aversion to the risk, adoption of timber-based systems was boosted significantly (Figure $19 \mathrm{~B}$ and Figure $20 \mathrm{~B}$ ). Combined effect of better timber market and extension would likely speed up the timber adoption (Figure 19 C and Figure 19 C). If better fire control was part of the effort, Imperata grasslands could be reduced (Figure $19 \mathrm{D}$ and Figure $20 \mathrm{D}$ ).

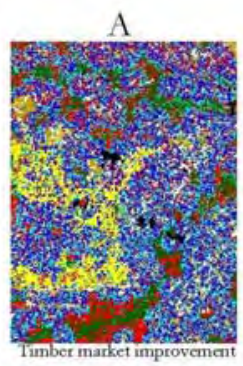

C

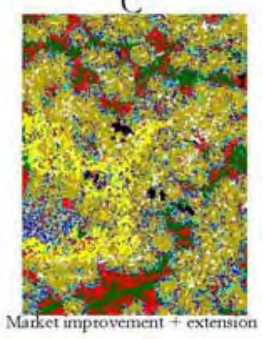

B

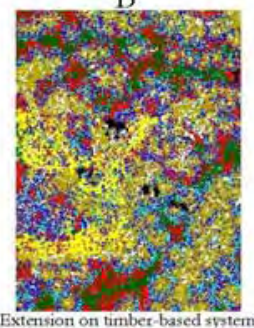

D

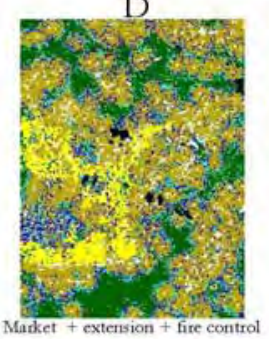

\section{Land use type}

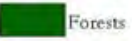

Homegarden

Timber plantation

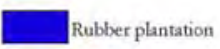

Oil palm plantation

Imperata/fallow

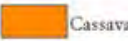

Sugarcane

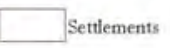

Figure 19. Prospects of final patterns of simulated landscape in the year-30 at various smallholder timber-based systems adoption scenarios.
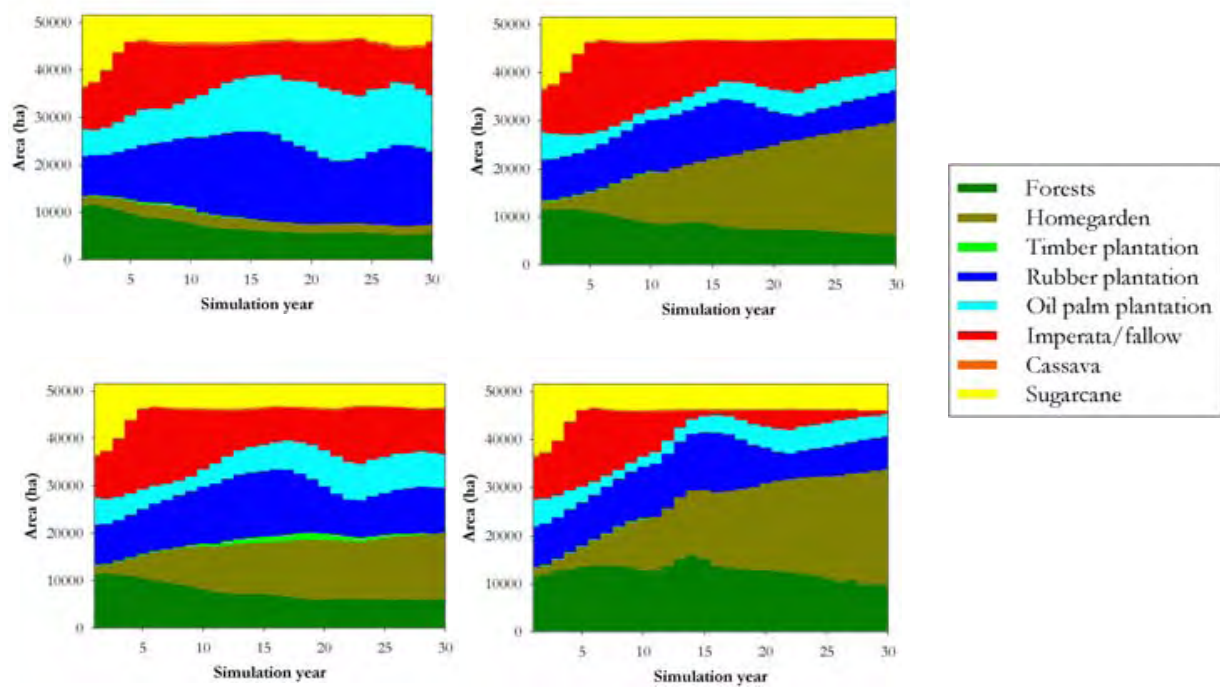

Figure 20. Prospects of landscape dynamics at various timber-based systems adoption scenarios over 3 decades.

From all scenarios in this part, farmers would likely prefer to adopt timber species in homegarden systems, instead of in monoculture plantation systems (Figure 21), due to reasons related to controlling costs. 


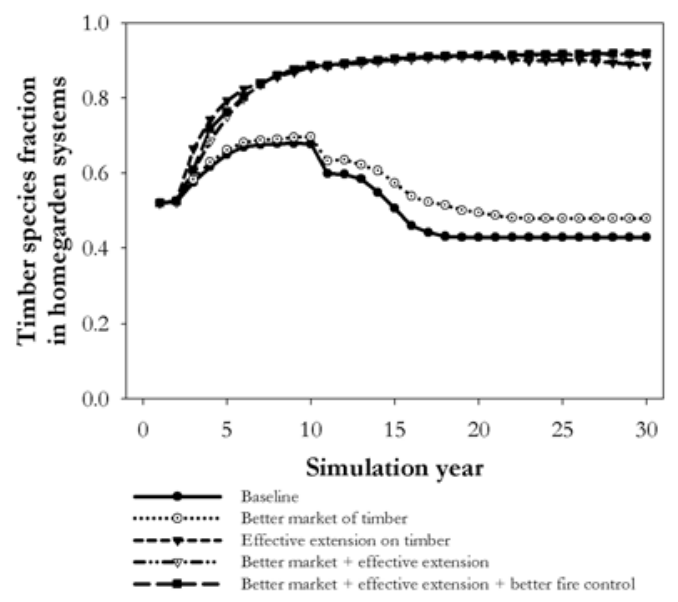

Figure 21. Prospects of timber-species adopted within homegarden systems at various timber-based systems adoption scenarios over 3 decades.

Impacts of timber-based systems revolution in the landscape would likely increase landscape c-stocks, as well as farmers' welfare (Figure 22), compared to the 'baseline'.
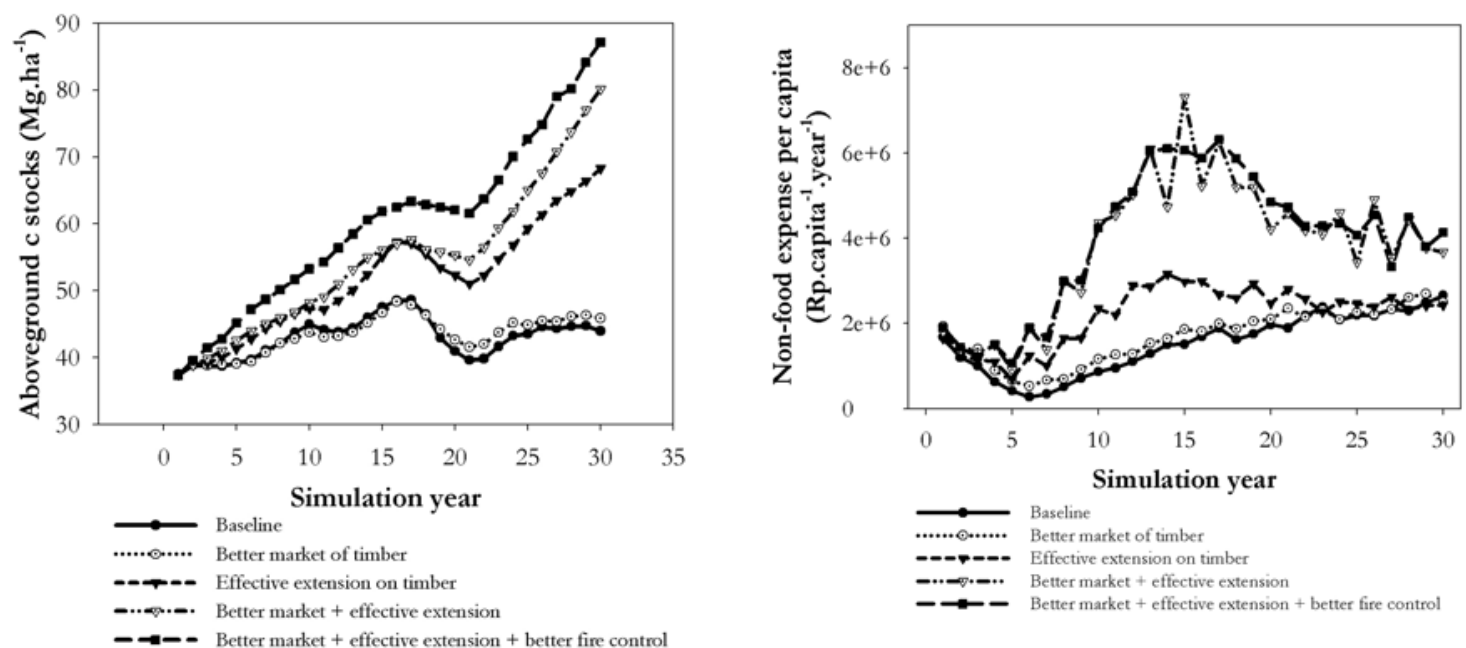

Figure 22.. Prospects of c stocks dynamics and farmers' welfare at various timber-based systems adoption scenarios over 3 decades.

\section{Prospecting the timber plantation ( HTI ) projects}

In this part, prospects of timber plantation (HTI) project approach were explored in a 'clean development mechanism' context. A 4256-ha hypothetical project boundary was set (Figure 23) replacing large-scale sugarcane plantation area, occupying $13 \%$ of knowledge zone 2 that covers transmigrants villages in the center of the study site (Negara Jaya, Tegal Mukti, Bima Sakti and Karang Sakti), 5\% of knowledge zone 3 that covers local villages in the southern part of the study site (Ujung
Karang and Karang Mua), and $0 \%$ of knowledge zone 1 that covers local villages in the northern part of the study site (Sri Menantui and Negeri Besar). Four types of projects were prospected, which were stratified based on harvesting cycle and off-farm employment: (i) HTI project with long harvesting cycle (30-year rotation) without employment; (ii) HTI project with long harvesting cycle (30-year rotation) with employment; (iii) HTI project with short harvesting cycle (10-year rotation) without employment; and (iv) HTI project with short harvesting cycle (10-year rotation) with employment. 

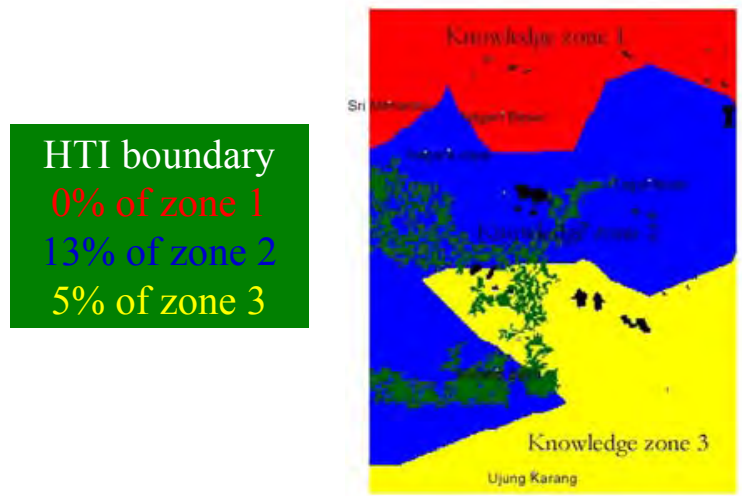

Figure 23. Hypothetical HTI boundary project used for simulations.

In term of landscape dynamics, it is clear that projects with employment would likely save the landscape refugia (remaining forests in the landscape) than projects without employment (Figure 24 and Figure 25).

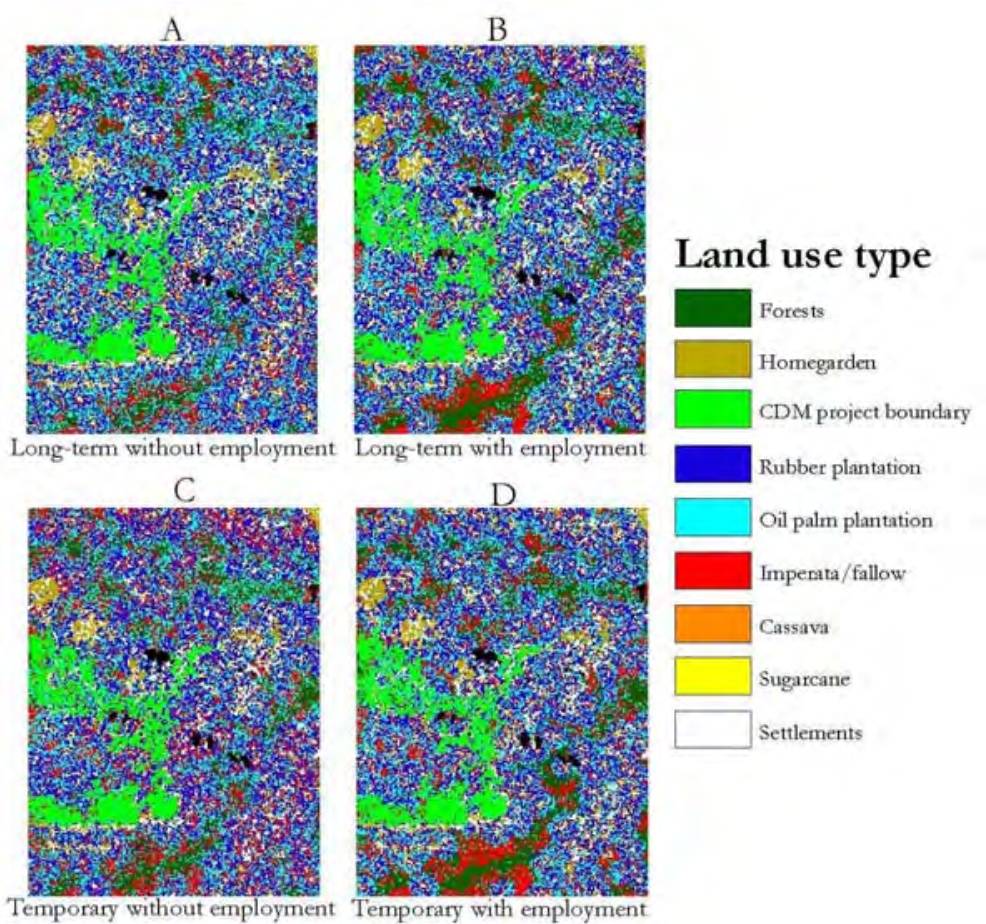

Figure 24. Prospects of final patterns of simulated landscape in the year-30 at various HTI scenarios. 

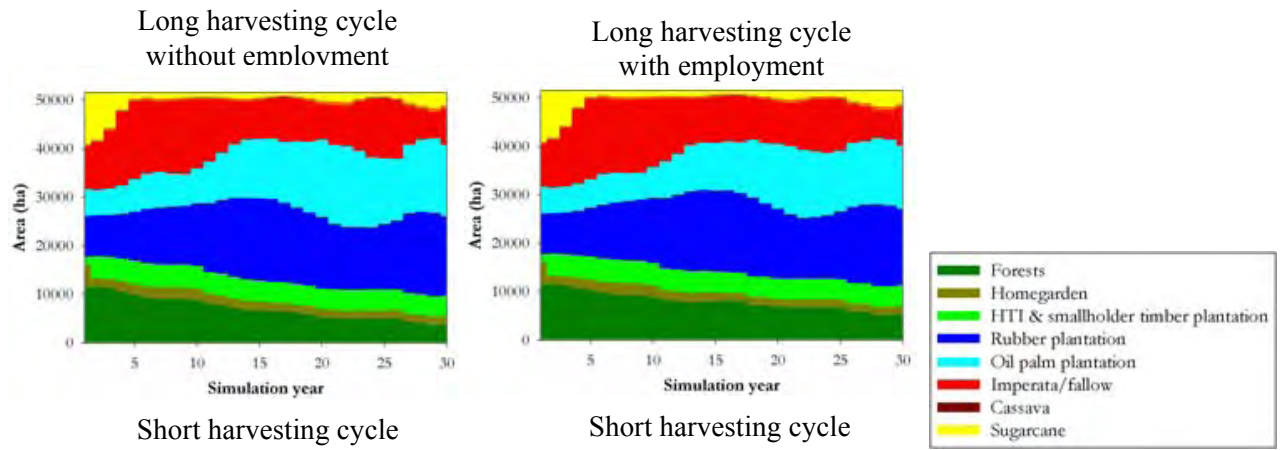

Short harvesting cycle without employment
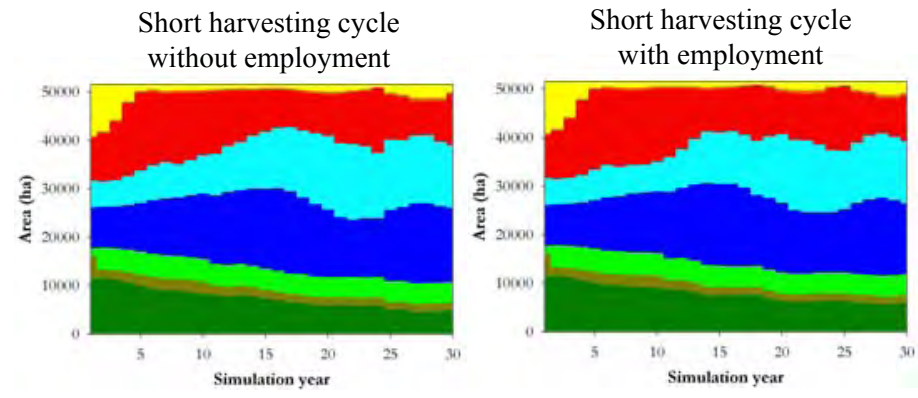

Figure 25. Prospects of landscape dynamics at various HTI scenarios over 3 decades.

In term of c-stocks within the project boundary, all types of projects would likely gain carbon higher than the 'baseline', with variation in sequestration dynamics related to cutting rotations (Figure 26). No significant difference was found in carbon gains outside the project boundary from all types of projects compared to the 'baseline' (Figure 27A). But, relatively small difference was found in landscape c-stocks, where projects with employment would likely increase carbon from the 'baseline' a bit higher than ones without employment (Figure 27B), because farmers would likely shift their labour allocation into new development of lower-carbon land use system of oil palm plantation, when the projects did not create off-farm employment.

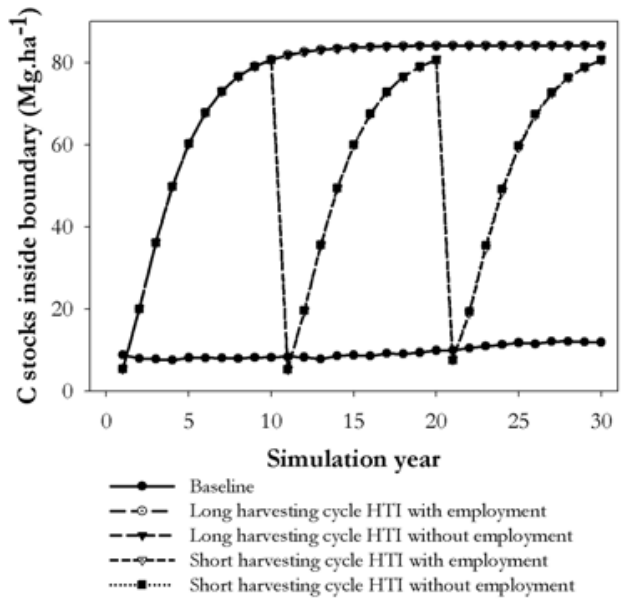

Figure 26. Prospects of c stocks dynamics within project boundary at various HTI scenarios over 3 decades. 

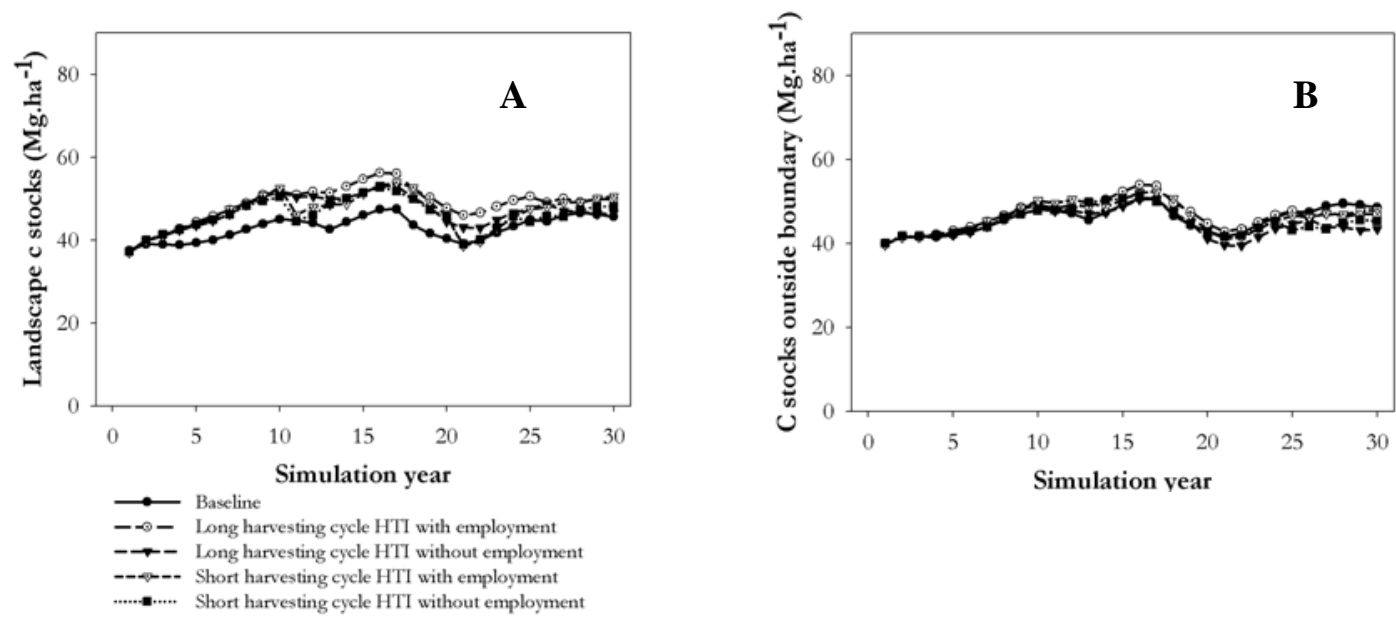

Figure 27. A. Prospects of c stocks dynamics outside project boundary at various HTI scenarios over 3 decades; B. Prospects of overall landscape c stocks dynamics at various HTI scenarios over 3 decades.

In term of impacts of the projects on farmers' welfare, it was obvious that all projects would likely decrease farmers' welfare from the 'baseline', since such projects would reduce on-farm areas for surrounding farmers (Figure 28). From the simulation results, knowledge zone 2 was the most affected zone, followed by knowledge zone 3 . When the project created off-farm employment for surrounding farmers, crash on welfare could likely be abated.

\section{Without projects}

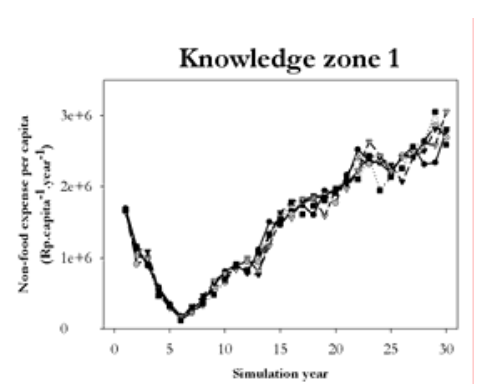

Projects occupied $5 \%$ of the area

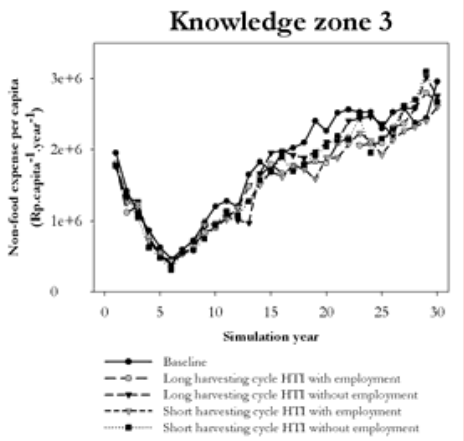

Projects occupied $13 \%$ of the area

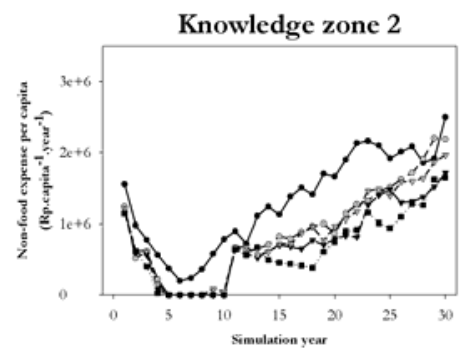

Figure 28. Prospects of farmers' welfare within 3 knowledge zones at various HTI scenarios over 3 decades.

\section{CONCLUSION}

Summaries of carbon and welfare based on the results from all scenario-based simulations were made with regards to 'clean development mechanism' context, to compare a 'project' approach to a programmatic one. Two monitoring periods were made to compare the approaches with the 'baseline': (i) short-term monitoring period of 20082012, referring to Kyoto commitment period (Table 1 and Table 2) and (ii) long-term monitoring period of 2002-2031, to prospect the 'real resilience' of CDM (Table 3 and Table 4). The results suggested that a 'project' approach was likely able to increase carbon stocks without leakage in a short-term monitoring period (Table 1 and Figure $28 \mathrm{~A}$ ). However a reduction of carbon stocks below baseline ('leakage') can be expected in the longer term if the tree planting approach did not provide off-farm employment opportunities to surrounding farmers (Table 2). If costs of 'extension' and 'social control on fire' are assumed to be zero, the 'programmatic' approach to removing constraints to spontaneous smallholder adoption was likely able to increase both carbon stocks and farmers' welfare better than the simulated 'project' approach (Figure 29). 
Table 1. Summary of carbon and welfare due to HTI projects approach over commitment period of 2008-2012.

\begin{tabular}{|l|l|l|l|l|l|}
\hline $\begin{array}{l}\text { Project approach } \\
\text { (HTI) }\end{array}$ & $\begin{array}{l}\text { Increase time } \\
\text { averaged of c- } \\
\text { stocks at project } \\
\text { scale over } \\
\text { commitment period } \\
2008-2012(\mathrm{Gg})\end{array}$ & $\begin{array}{l}\text { Increase time } \\
\text { averaged c-stocks } \\
\text { at landscape scale } \\
\text { over commitment } \\
\text { period 2008-2012 } \\
(\mathrm{Gg})\end{array}$ & $\begin{array}{l}\text { Carbon leakage } \\
\text { over commitment } \\
\text { period 2008-2012 } \\
(\%)\end{array}$ & $\begin{array}{l}\text { Increase time } \\
\text { averaged of non- } \\
\text { food expense per } \\
\text { capita over } \\
\text { commitment period } \\
2008-2012 \\
\text { (Rp.capita-1.yr-1) }\end{array}$ & $\begin{array}{l}\text { Increase time } \\
\text { averaged of non- } \\
\text { food expense per } \\
\text { capita relative to } \\
\text { baseline over } \\
\text { commitment period } \\
\text { 2008-2012 }\end{array}$ \\
\hline $\begin{array}{l}\text { Short harvesting } \\
\text { cycle without } \\
\text { employment }\end{array}$ & 233.15 & 234.82 & -0.72 & $-2.22 . \mathrm{E}+05$ & -31.57 \\
\hline $\begin{array}{l}\text { Long harvesting } \\
\text { cycle without } \\
\text { employment }\end{array}$ & 298.34 & 324.21 & -8.67 & $-1.80 . E+05$ & -24.31 \\
\hline $\begin{array}{l}\text { Short harvesting } \\
\text { cycle with } \\
\text { employment }\end{array}$ & 233.13 & 308.84 & -32.48 & $-1.92 . \mathrm{E}+05$ & -28.18 \\
\hline $\begin{array}{l}\text { Long harvesting } \\
\text { cycle with } \\
\text { employment }\end{array}$ & 298.34 & 354.36 & -18.78 & $-2.17 . \mathrm{E}+05$ & -31.19 \\
\hline
\end{tabular}


Table 2. Summary of carbon and welfare due to programmatic approach over commitment period of 2008-2012.

\begin{tabular}{|l|l|l|l|}
\hline Programmatic approach & $\begin{array}{l}\text { Increase time averaged of c- } \\
\text { stocks at landscape scale over } \\
\text { commitment period 2008- } \\
2012(\mathrm{Gg})\end{array}$ & $\begin{array}{l}\text { Increase time averaged of } \\
\text { non-food expense per capita } \\
\text { over commitment period 2008- } \\
2012\left(\mathrm{Rp}_{\text {ccapita }}{ }^{-1} \mathrm{yr}^{-1}\right)\end{array}$ & $\begin{array}{l}\text { Increase time averaged of } \\
\text { non-food expense per capita } \\
\text { relative to baseline over } \\
\text { commitment period 2008- } \\
2012(\%)\end{array}$ \\
\hline Better social control on fire & 220.65 & $7.77 \mathrm{E}+04$ & 9.65 \\
\hline Timber market improvement & -39.40 & $2.64 \mathrm{E}+05$ & 44.84 \\
\hline $\begin{array}{l}\text { Effective extension on timber- } \\
\text { based systems }\end{array}$ & 162.50 & $1.09 \mathrm{E}+06$ & 168.39 \\
\hline $\begin{array}{l}\text { Better timber market }+ \\
\text { effective extension on timber- } \\
\text { based systems }\end{array}$ & 207.37 & $2.52 \mathrm{E}+06$ & 367.11 \\
\hline $\begin{array}{l}\text { Better timber market }+ \\
\text { effective extension on timber- } \\
\text { based systems }+ \text { better social } \\
\text { control on fire }\end{array}$ & 459.82 & $2.65 \mathrm{E}+06$ & 393.66 \\
\hline
\end{tabular}

Table 3. Summary of carbon and welfare due to HTI projects approach over 30-year period (2002-2031).

\begin{tabular}{|l|l|l|l|l|l|}
\hline $\begin{array}{l}\text { Project approach } \\
(\mathrm{HTI})\end{array}$ & $\begin{array}{l}\text { Increase time } \\
\text { averaged of c- } \\
\text { stocks at project } \\
\text { scale over 30-yr } \\
\text { period }(\mathrm{Gg})\end{array}$ & $\begin{array}{l}\text { Increase time } \\
\text { averaged of c- } \\
\text { stocks at landscape } \\
\text { scale over 30-yr } \\
\text { period }(\mathrm{Gg})\end{array}$ & $\begin{array}{l}\text { Carbon leakage } \\
\text { over 30-yr period } \\
(\%)\end{array}$ & $\begin{array}{l}\text { Increase time } \\
\text { averaged of non- } \\
\text { food expense per } \\
\text { capita over 30-yr } \\
\text { period (Rp.capita- } \\
\text { '.yr-1) }\end{array}$ & $\begin{array}{l}\text { Increase time } \\
\text { averaged of } \\
\text { annual non-food } \\
\text { expense per capita } \\
\text { relative to baseline } \\
\text { over 30-yr period } \\
(\%)\end{array}$ \\
\hline $\begin{array}{l}\text { Short harvesting } \\
\text { cycle without } \\
\text { employment }\end{array}$ & 192.98 & 169.28 & 12.28 & $-2.88 . E+05$ & -22.03 \\
\hline $\begin{array}{l}\text { Long harvesting } \\
\text { cycle without } \\
\text { employment }\end{array}$ & 275.58 & 218.36 & 20.76 & $-2.26 . E+05$ & -17.11 \\
\hline $\begin{array}{l}\text { Short harvesting } \\
\text { cycle with } \\
\text { employment }\end{array}$ & 192.56 & 218.72 & -13.58 & $-2.42 . E+05$ & -18.16 \\
\hline $\begin{array}{l}\text { Long harvesting } \\
\text { cycle with } \\
\text { employment }\end{array}$ & 275.58 & 321.93 & -16.82 & $-2.06 . E+05$ & -16.81 \\
\hline
\end{tabular}

Table 4. Summary of carbon and welfare due to programmatic approach over 30-year period (2002-2031).

\begin{tabular}{|l|l|l|l|}
\hline Programmatic approach & $\begin{array}{l}\text { Increase time averaged of c- } \\
\text { stocks at landscape scale over } \\
30-y r \text { period }(\mathrm{Gg})\end{array}$ & $\begin{array}{l}\text { Increase time averaged of } \\
\text { non-food expense per capita } \\
\text { over 30-yr period (Rp.capita- } \\
\text { '.yr-1) }\end{array}$ & $\begin{array}{l}\text { Increase time averaged of } \\
\text { annual non-food expense per } \\
\text { capita relative to baseline } \\
\text { over 30-yr period (\%) }\end{array}$ \\
\hline Better social control on fire & 246.38 & $4.58 \mathrm{E}+04$ & 2.78 \\
\hline Timber market improvement & 21.90 & $1.84 \mathrm{E}+05$ & 21.30 \\
\hline $\begin{array}{l}\text { Effective extension on timber- } \\
\text { based systems }\end{array}$ & 481.81 & $6.86 \mathrm{E}+05$ & 73.41 \\
\hline $\begin{array}{l}\text { Better timber market }+ \\
\text { effective extension on timber- } \\
\text { based systems }\end{array}$ & 646.06 & $2.32 \mathrm{E}+06$ & 195.13 \\
\hline $\begin{array}{l}\text { Better timber market }+ \\
\text { effective extension on timber- } \\
\text { based systems }+ \text { better social } \\
\text { control on fire }\end{array}$ & 937.47 & $2.46 \mathrm{E}+06$ & 206.56 \\
\hline
\end{tabular}

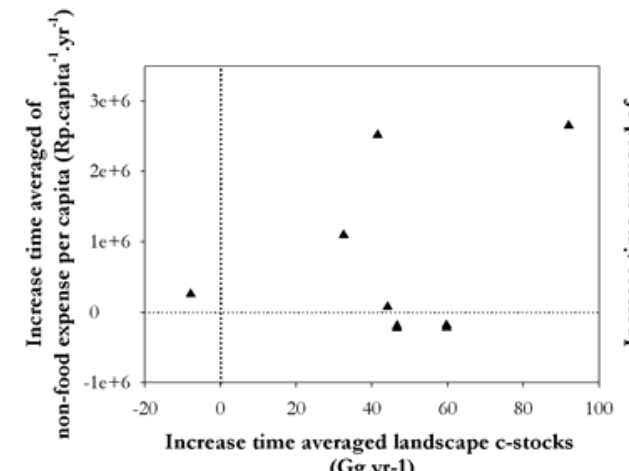

(Gg.yr-1)

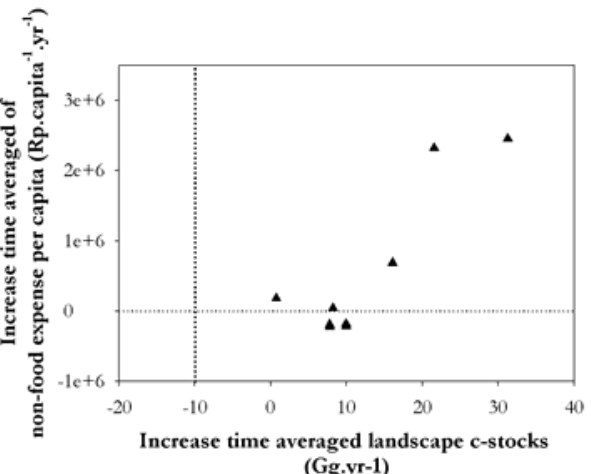

(Gg.yr-1)

Figure 29. Summary of carbon and welfare due to programmatic approach and project approach. 


\section{ACKNOWLEDGEMENT}

This activity is funded by Australian Centre for International Agricultural Research (ACIAR) through ASEM 2002/066 Project and Common Fund for Commodities (CFC)-Improving the Productivity of Rubber Smallholdings through Rubber Agroforestry Systems (CFC/IRSG/11) Project.

\section{LITERATURE CITED}

Gladwell, M. 2005. Blink: The Power of Thinking Without Thinking. Little, Brown and Company.

Peterson, G.D., Cumming, G.S., and Carpenter, S.R. 2003. Scenario planning: a tool for conservation in an uncertain world. Conservation Biology 17(2): pp. 358-366.

Suyamto, D.A. and Van Noordwijk, M. 2005. Scenario studies of land use in Nunukan, East Kalimantan (Indonesia): drivers, local livelihoods and globally relevant carbon stocks. In: Lusiana, B., Van Noordwijk, M., and Rahayu, S. (Eds.): Carbon Stocks Monitoring in Nunukan, East Kalimantan: a Spatial and Modelling Approach. Report from Carbon Monitoring Team of the Forest Resources Management for Carbon Sequestration (FORMACS) Project. World Agroforestry Center. pp: 55-77.

Van Noordwijk, M., T.P. Tomich, R. Winahyu, D. Murdiyarso, S. Partoharjono and A.M. Fagi (editors) 1995. Alternatives to Slash-and-Burn in Indonesia, Summary Report of Phase 1. ASB-Indonesia Report Number 4, Bogor, Indonesia, $154 \mathrm{pp}$

Van Noordwijk, M. 2002. Scaling trade-offs between crop productivity, carbon stocks and biodiversity in shifting cultivation landscape mosaics: the FALLOW model. Ecological Modelling 149: 113-126.

Voros, J. 2005. Speaking about the future: ‘pro-vocation' and 'ante-diction'. Futures 37: 87-96. 


\section{List of Southeast Asia Working Papers}

\section{5}

Fay CC and Sirait MT. 2005. Kerangka hukum negara dalam mengatur agraria dan kehutanan Indonesia: Mempertanyakan sistem ganda kewenangan atas penguasaan tanah. ICRAF Southeast Asia Working Paper, No. 2005_3. Bogor, Indonesia. World Agroforestry Centre - ICRAF, SEA Regional Office. $17 \mathrm{p}$.

Colchester M, Eka Dinata A, Fay CC, Pasya G, IE, Situmorang L, Sirait MT, van Noordwijk M, Cahyaningsih N, Budidarsono S, Suyanto S, Kusters K, Manalu P and Gaveau D. 2005. Facilitating agroforestry development through land and tree tenure reforms in Indonesia. ICRAF Southeast Asia Working Paper, No. 2005_2. Bogor, Indonesia. World Agroforestry Centre - ICRAF, SEA Regional Office. 51 p.

Bratamihardja M, Sunito S and Kartasubrata J. 2005. Forest management in Java 1975 - 1999. ICRAF Southeast Asia Working Paper, No. 2005_1. Bogor, Indonesia: World Agroforestry Centre - ICRAF, SEA Regional Office. 28p.

\section{4}

Gatmaytan AB and Dagondon GO. 2004. Sustainability and survival four case studies from indigenous communities in Northern Mindanaw. ICRAF Southeast Asia Working Paper, No. 2004_5. Bogor, Indonesia: World Agroforestry Centre ICRAF, SEA Regional Office. 53p.

Roshetko JM, Mulawarman and Dianarto A. 2004. Jalur perolehan peredaran benih pohon di Wonogiri dan Ponorogo, Jawa: sumber utama benih pohon di Indonesia. ICRAF Southeast Asia Working Paper, No 2004_4. Bogor, Indonesia: World Agroforestry Centre - ICRAF, SEA Regional Office. $16 \mathrm{p}$.

Joshi L, Wijaya K, Sirait MT and Mulyoutami E. 2004. Indigenous systems and ecological knowledge among Dayak people in Kutai Barat, East Kalimantan-a preliminary yreport. ICRAF Southeast Asia Working Paper, No. 2004_3. Indonesia: World Agroforestry Centre ICRAF, SEA Regional Office. 22 p.

Sirait MT, Situmorang L, Galudra G, Fay CC and Pasya G. 2004. Kebijakan pengukuhan kawasan hutan dan realisasinya. ICRAF Southeast Asia Working Paper, No. 2004_2. Bogor, Indonesia: World Agroforestry Centre - ICRAF, SEA Regional Office. 14 p.
Roshetko JM, Mulawarman and Dianarto A. 2004. Tree seed procurement-diffusion pathways in Wonogiri and Ponorogo, Java: Indonesia's main source of tree seed. ICRAF Southeast Asia Working Paper, No. 2004_1. Bogor, Indonesia: World Agroforestry Centre - ICRAF, SEA Regional Office. $16 \mathrm{p}$.

2003

Galudra G. 2003. Conservation policies versus reality. ICRAF Southeast Asia Working Paper, No. 2003_4. Bogor, Indonesia. : World Agroforestry Centre ICRAF, SEA Regional Office. 28 p.

Galudra G. 2003. Kasepuhan and their socioculture interaction to the forest. ICRAF Southeast Asia Working Paper, No. 2003_3. Bogor, Indonesia: World Agroforestry Centre - ICRAF, SEA Regional Office. 15 p.

van Noordwijk M, Roshetko JM, Murniati, Angeles Md, Suyanto S, Fay CC and Tomich TP. 2003. Agroforestry is a form of sustainable forest management: lessons from South East Asia. ICRAF Southeast Asia Working Paper, No. 2003_2. No. Bogor, Indonesia: World Agroforestry Centre ICRAF, SEA Regional Office. 18 p.

Gouyon A. 2003. Eco-Certification as an incentive to conserve biodiversity in rubber smallholder agroforestry systems: a preliminary study. ICRAF Southeast Asia Working Paper, No. 2003_1. Bogor, Indonesia: World Agroforestry Centre - ICRAF, SEA Regional Office. 58 p.

\section{2}

van Noordwijk M, Boutin D, Swibawa IG, Beukema HJ and Joshi L. 2002. Options for smallholder rubber producers to increase productivity while maintaining 'forest functions'. ICRAF Southeast Asia Working Paper, No. 2002_2. Bogor, Indonesia: International Centre for Research in Agroforestry, SEA Regional Research Programme. 12 p.

van Noordwijk M. 2002. ICRAF the World Agroforestry Centre - who we are in Southeast Asia, what we do, where and why. ICRAF Southeast Asia Working Paper No. 2002_1. Bogor, Indonesia: International Centre for Research in Agroforestry, SEA Regional Research Programme. $12 \mathrm{p}$. 


\section{ICRAF Working Papers}

1. Agroforestry in the drylands of eastern Africa: a call to action

2. Biodiversity conservation through agroforestry: managing tree species diversity within a network of community-based, nongovernmental, governmental and research organizations in western Kenya.

3. Invasion of prosopis juliflora and local livelihoods: Case study from the Lake Baringo area of Kenya

4. Leadership for change in Farmers Organizations: Training report: Ridar Hotel, Kampala, 29th March to 2nd April 2005

5. Domestication des espèces agroforestières au Sahel : situation actuelle et perspectives

6. Relevé des données de biodiversité ligneuse: Manuel du projet biodiversité des parcs agroforestiers au Sahel

7. Improved Land Management in the Lake Victoria Basin: TransVic Project's Draft Report

8. Livelihood capital, strategies and outcomes in the Taita hills of Kenya

9. Les espèces ligneuses et leurs usages: Les préférences des paysans dans le Cercle de Ségou, au Mali

10. La biodiversité des espèces ligneuses: Diversité arborée et unités de gestion du terroir dans le Cercle de Ségou, au Mali

11. Bird diversity and land use on the slopes of Mt. Kilimanjaro and the adjacent plains, Tanzania

12. Water, women and local social organization in the Western Kenya Highlands

13. Highlights of ongoing research of the World Agroforestry Centre in Indonesia

14. Prospects of adoption of tree-based systems in a rural landscape and its likely impacts on carbon stocks and farmers' welfare: the FALLOW Model Application in Muara Sungkai, Lampung, Sumatra, in a 'Clean Development Mechanism' context 


\section{Who we are}

The World Agroforestry Centre is the international leader in the science and practice of integrating 'working trees' on small farms and in rural landscapes. We have invigorated the ancient practice of growing trees on farms, using innovative science for development to transform lives and landscapes.

\section{Our vision}

Our Vision is an 'Agroforestry Transformation' in the developing world resulting in a massive increase in the use of working trees on working landscapes by smallholder rural households that helps ensure security in food, nutrition, income, health, shelter and energy and a regenerated environment.

\section{Our mission}

Our mission is to advance the science and practice of agroforestry to help realize an 'Agroforestry Transformation' throughout the developing world.

\section{F U T U R E H A RY/EST CGIAR}

A Future Harvest Centre supported by the CGIAR

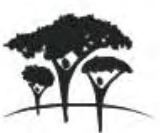

United Nations Avenue, Gigiri - PO Box 30677 - 00100 Nairobi, Kenya Tel: +254207224000 or via USA +1 6508336645 Fax: +254207224001 or via USA +1 6508336646

Southeast Asia Regional Programme - Sindang Barang, Bogor 16680 PO Box161 Bogor 16001, Indonesia Tel: +62 251625415 - Fax: +62251625416 www.worldagroforestry.org 